\title{
Is population really a problem?
}

\begin{abstract}
Background: Dialogue pertaining to the effects of population decline and/or growth has been studied since the eighteenth century. For example, many French writers like Montesquieu were concerned about the declining population of France and advocated employment generation activities to increase the size of the populace. Similarly, Victor Riqueti, Marquis de Mirabeau argued that governments should promote population growth as it is essential for economic growth of a country.
\end{abstract}

Methods: The methodology adopted for this paper was Narrative Review.

Results: Hume recognised the importance of happiness, freedom, hard-work and equality as essential elements for populations to survive. Various thinkers recognised the importance of large populations and inter-linked population growth associated with socio-economic determinants. But during the late eighteenth century, the viewpoints changed and the different argument of population growth was put forward by Robert Wallace, Benjamin Franklin, and Thomas Robert Malthus. In 1798, Malthus published, "An Essay on the Principle of Population" and provided a theoretical concept known as "Malthusian Catastrophe". Marx and Engels in the 20th century counter-argued Malthusian Catastrophe. In the late nineteenth century, neo-malthusians presented philosophies pertaining to survival of the fittest, natural selection, eugenics and contraception. In 1968, American Demographer Kingsley Davis attracted the world's attention to the population situation of India and Pakistan and argued that a decline in mortality was not followed by a decline in birth rate in these countries in which he considered a problem. The developed world was convinced that population growth in developing countries is a threat to survival and it should be given priority in funding to address it. The International Conference on Population and Development (ICPD) at Cairo consisted of a paradigm shift talk of reproductive rights and reproductive health. It abhorred the target oriented approach of coercive family planning programmes. The same ideology was carried forward by the Millennium Development Goals and now the Sustainable Development Goals.

Conclusion: Population in itself is not a problem but the miseries of populations possess problems which should be analysed and treated.

Keywords: population, Malthus; population problem, Malthusian catastrophe, development, Cairo, agricultural taxation, Malthusian catastrophe, ibid, govt. of India, ministry of law and justice, victor Riqueti, marquis de Mirabeau
Volume 5 Issue 5 - 2017

\section{Rohini Ruhil}

Centre for Social Medicine and Community Health, Jawaharlal Nehru University, India

Correspondence: Rohini Ruhil, Centre for Social Medicine and Community Health, Jawaharlal Nehru University, India, Tel +91 704227/444, Email drrohiniruhil@gmail.com

Received: January 31, 2017 | Published: April 17, 2017
Abbreviations: ICPD, international conference on population and development; CEDAW, convention on the elimination of all forms of discrimination against women; NRR, net reproductive ratio; TFR, total fertility rate; MTP, termination of pregnancy; PNDT, pre-natal diagnostic techniques

\section{Background}

In the eighteenth century, French intellectuals were worried about the declining population size in their country. ${ }^{1}$ Montesquieu in his writings attributed this decline in population growth to people adhering to the principles of the Catholic Church and also to oppressive economic policies like agricultural taxation. He advocated employment generation and political liberty as facilitators to increase their population. ${ }^{2}$ Other writers of eighteenth century such as Victor Riqueti Marquis de Mirabeau also promoted population growth as essential for the economic development of a country. ${ }^{3}$ In 1767 , Sir James Steuart emphasized that employment and hard-work was essential for the propagation of modern societies. ${ }^{2}$ The social scientists of the early eighteenth century unanimously favored large populations as a symbol of prosperity and interlinked population growth associated with positive socio-economic determinants. ${ }^{4}$ These thinkers understood that population size was a dependent variable providing an eco-social perspective of looking at population issues and linking them with social, cultural and political factors. The perceptions of population growth changed during the late eighteenth century and the principles pertaining to the geometrical increase in population were put forward by Robert Wallace, Benjamin Franklin and Thomas Robert Malthus. ${ }^{4}$ The Malthusian theory became highly popular and has been constantly taught in demography as a discipline.

\section{Methodology}

The methodology adopted was Narrative Review. Search engines used were Google, Google Scholar, DOAJ, PubMed, and the JNU library online database. Various books were also consulted. Relevant articles were selected based on the author's discretion. No prespecified inclusion/exclusion criteria were defined. Inductive thematic analysis was utilized for data extraction and analysis. Major and minor themes were reported. When the saturation of themes was reached, the process was stopped.

\section{Result}

In 1798 Malthus published, "An Essay on the Principle of 
Population" and provided a theoretical concept, popularly referred to as the "Malthusian Catastrophe". ${ }^{5}$ He proposed that the means of subsistence grows in an arithmetic ratio while the population size increases in a geometric proportion and if left unchecked it comes to a point when the resources are no longer able to support the growing populace (ibid). Malthus' ideas were accepted widely, and as a result, England accelerated the passing of the Census Act in 1800. The general report on the Census of India, 1891 indicated that overpopulation size was responsible for poverty manifesting in the country. ${ }^{4}$ Subsequent censuses reinforced the same belief although actual population growth was not revealed until in the 1931 census (ibid). The stagnation in the Indian economy starting in 1860s occurred during a long period of time prior to the increase in Indian population. ${ }^{6}$ Thus Indian poverty could not be attributed to population increase. The "loot" during British colonial period was very much responsible for misery of Indians. Subsequently, Marx and Engels counterargued Malthus. Engels questioned the arithmetical progression in productivity of land. He argued that with the increase in population, labour is also increasing and also there is limitless progress in science to increase the productivity of land. ${ }^{7}$ Engel also argued that the 'law of diminishing returns' is inapplicable in analysing the effects of the constantly improving technology. In the nineteenth century, the England population increased along with the rise in per capita income demonstrating a phenomenon that differed from the theory proposed by Malthus. ${ }^{4}$ In 1967, Kuznets and Easterlin also noted that there no correlation exists between population growth in developing countries and their economic growth (ibid). In late nineteenth century, NeoMalthusians came with ideas of survival of the fittest, natural selection, eugenics and contraception. ${ }^{8}$ The concepts of positive and negative eugenics were proposed by Galton and Clapperton, respectively. According to Galton the best and brightest could be encouraged to breed $^{9}$ whereas Clapper ton analysed the criminals, insane, mentally disabled, and severely ill. ${ }^{8}$ In 1933, Adolf Hitler passed a eugenic sterilisation law under which people suffering from hereditary disabilities were sterilised and prevented from getting married. ${ }^{10}$ In the US, a similar eugenics movement was also started and an IQ test was made mandatory for immigration in US. Eugenic sterilizations of psychotics, epileptics and mentally impaired began. ${ }^{11}$ The victims of this eugenics utopia were the weak and powerless, for example: to be eligible for welfare in the US women with records of criminal history or child neglect must have been implanted with Norplant. The majority of these US women implanted with Norplant were African-Americans or Hispanics. ${ }^{12}$ The famous biologist JBS Haldane scientifically discredited Eugenics. Then in the early 1940s Herman Mueller discovered how the phenomena of genetic mutations ended the era of eugenics. Eugenists then supported the concept of Cryptoeugenics or population control. ${ }^{4}$ The radical feminist movements also started in late eighteenth century which asserted rights of women to control their own bodies. Also, the class of working women emerged and demanded birth control rights. ${ }^{13}$ They believed that repeated pregnancies were harmful to the bodies of working women and as result, they demanded free access to contraceptives (ibid). Population control activities initiated by working women led to the social norm of having two children per couple.

In 1968, American demographer Kingsley Davis attracted the world's attention to the population situation of India and Pakistan. ${ }^{14}$ $\mathrm{He}$ argued that the decline in death rate was not followed by decline in birth rate in these countries and posed it as a problem. After that stance, the trend started of blaming India's population growth being responsible for its poverty. The first family planning clinic of India was started in 1925 which later led to the formulation of the official family planning policy. The developed world was convinced that the increasing population growth in developing countries was a threat to survival and should be addressed through the implementation of policies and funding which was received from the Ford and Rockefeller Foundations. ${ }^{4}$ It is important here to mention that the scars of the family planning programme of the emergency period led to 1,774 reported deaths and about 7 million forced sterilisations involving bachelors, hospital patients, old persons, persons with no children, jail inmates, pavement dwellers and inmates in night shelters. ${ }^{15}$ As a consequence, people started avoiding hospitals and health services including vaccination due to fear of being nabbed for sterilisation (ibid). The International Conference on Population and Development (ICPD) at Cairo in 1994 involved a paradigm shift discussing and promoting the reproductive rights and reproductive health of women. It abhorred the target oriented approach of coercive family planning programmes. The article 16 of UN Convention on the Elimination of all Forms of Discrimination against Women (CEDAW) also talked about the rights of reproductive choice of women. The Cairo Conference discussed in particular about the right to legal abortions because the religious fundamentalists in the USA, Vatican, and conservative Islamic countries were against abortion influenced policy decisions to support their stance. ${ }^{16}$ The ICPD was revolutionary in the way population problem was understood. The focus then shifted to women's empowerment and reproductive health. ${ }^{17}$ There was also criticism of 'Cairo Consensus' by some organisations that termed it as an 'old wine in a new bottle' and associated it with neo-liberal globalization. ${ }^{18}$ The national and international organisations realised that education and employment were equally important in reducing birth rate along with modern contraception. ${ }^{19}$ It was also realised that the role of women could not be confined to reproduction only and that increased status of women in society would automatically help in population stabilisation. At the time of the Cairo Conference, India had a strong anti-natalist family planning program guided by the principle that the Net Reproductive Ratio (NRR) equals to one as explained in the National Health Policy (1983). The Swaminathan Committee in 1994 recommended 'the abandonment' of specific targets for contraception and also discontinuation of incentives for the acceptors of contraceptives. ${ }^{20}$ But the committee also faced widespread criticism for proposing disincentives such as debarring persons with more than two living children from contesting elections in panchayats and adoption of 'two children' norm being mandatory for recruitment and promotion in government jobs (ibid). These measures led to the consequences of "additional children being hidden away with relatives, and wives being deserted". ${ }^{21}$ Afterward, many policies influenced population and reproductive health issues in India including the National Population policy (2000), National Policy for the Empowerment of Women (2001), National AIDS Prevention and Control Policy (2002), National Health Policy (2002) and the National Youth Policy (2003). Along with other comprehensive goals, these policies also aimed at reducing the Total Fertility Rate (TFR).

The Child Marriage Restraint Act of 1929, 1978 and the Prohibition of Child Marriage Act 2006 have imposed a minimum age for marriage i.e. 18years old for girls and 21years old for boys; there is a provision for the prosecution of those violating the law (Ministry of Law and Justice 2007). The Medical Termination of Pregnancy (MTP) Act 1971 and its amendment (2002) allows women to terminate their pregnancies up to 20 weeks in special circumstances 
when it endangers their lives or health, unwanted pregnancies, in cases of rape, or the foetuses with physical or mental abnormalities (Govt. of India 1971, 2003). In 2002, the Mifepristone-Misoprostol combination was approved for usage by the Drugs Controller of India for the termination of early pregnancies. The Pre-Natal Diagnostic Techniques (Regulation and Prevention of Misuse) Act of 1994 (PNDT Act), and the 2002 amendments to the act (PCPNDT) was the landmark effort to curb the menace of sex-selective abortions in India. ${ }^{22}$ There were other laws including the Protection of Women from Domestic Violence Act 2005, the Immoral Traffic (Prevention) Amendment Bill 2006, the protection of children from Sexual Offences Act 2012, the Protection of Women against Sexual Harassment at Workplace Bill 2010, the Women's Reservation Bill (the Constitution 108th Amendment Bill) 2008, and the Right of Children to Free and Compulsory Education Act 2009 which were an attempt to improve the situation of women and children in India but their implementation needed to be strengthened. In the beginning of the 21st century, the Millennium Development Goals included investing in sexual and reproductive health. The new century consisted of the paradigm shift where the eradication of poverty is our prime concern. The concern of Population Control has shifted to Reproductive Health being primary concerned of reducing maternal mortality and infant/child mortality. There is continuous talk about sustainable development since 2000 and again in 2015 pertaining to the formulated Sustainable Development Goals which are comprehensive and aim toward eradicating hunger, poverty, maternal and child deaths and ensuring healthy lives and well-being.

\section{Discussion}

The age structures of populations change as they move through demographic transitions. Globally, countries differ in respect to their population structures and whether their populations are contracting, expanding or remaining static. In developed countries like Japan, Germany and many other European nations, population ageing and population shrinkage has become major public health concerns. It has been estimated that by 2047 the number of old people will exceed the number of children in the world. ${ }^{23}$ Also, it has been forecasted that almost every third person will be above 65 years of age by $2040 .{ }^{24}$ In India, the working age population is increasing which can be encashed in to lowering of the dependency ratio, a phenomenon called Demographic Dividend. This is an opportunity for India which if capitalised properly will largely benefit the Indian economy. ${ }^{25}$ The critical factors for utilising this dividend are education, employment and health status of people and thus link demography to developmental issues. The female workforce participation and women empowerment are also very important for harnessing demographic dividend.

The demographic transition theory has also illustrated the relationship between survival rates and birth rates. As more number of children survives till adulthood or old age, birth rates in a population begin to fall and the overall population growth rate begins to decline. ${ }^{26}$ The initial high levels of birth rates existed because of the high infant mortality and child mortality rates. In such a situation, families preferred large number of births so that at-least few of them would survive till adulthood (ibid). Also, the poverty levels were high and the child labour was prevalent. In such poor situations, children were considered as helping hands as they will soon join family labour work and will provide extra income to the family. ${ }^{27}$ Thus it would be wrong to say that poverty is a consequence of large families but it is the other way round that large families are consequences of poverty. ${ }^{28}$
The population size and fertility are socio-economic determinants. A curvilinear relationship exists between education and fertility. It was observed that women with a middle school education had a higher fertility in comparison to illiterate women but women with higher education had minimum fertility levels. ${ }^{4}$ similarly, there is a curvilinear relationship between levels of living and fertility. The fertility is lowest in the lowest income groups and also the richest income groups (Patel 1994). The fertility increases with increase in income up to a certain point; after that it starts declining with increase in further income. Various studies have found different relationships of family size with socio-economic status of families with the type of occupation being a confounding factor. The labouring and landlord classes have the large number of children and the service class has fewer children. ${ }^{4}$ The argument pertaining to the over-population size is that it is burdensome on resources. But in 1990, an estimated $86 \%$ of resources were consumed by $20 \%$ of world population living in highest income countries. The poorest $20 \%$ of world population consumed only $1.3 \%$ of global resources. Also the richest quartile consumes 150 times more resources than the poorest quartile. ${ }^{29}$ According to the UN estimates per capita energy consumption in US is 50 times more than per capita energy consumption in India..$^{30}$ Thus if we rationalize birth control in terms of energy saving; then prevention of one birth in US will be as effective as prevention of 50 births in India. ${ }^{4}$ In 1984, Simon showed that population growth has a rather positive effect on economic growth in the long run. ${ }^{31}$ Mamdani also argued that poverty is not a consequence of overpopulation rather overpopulation is a consequence of poverty. ${ }^{28}$ Thus we should priorities poverty eradication and development rather than channelizing all our energies towards population control. Ultimately the couple should decide the number of children they want to have rather than the tradition, religion, church, law or state..$^{29-38}$

\section{Conclusion}

In 1974, then Indian Minister of Health and Family Planning stated at the World Population Conference in Bucharest that, "Development is the Best Contraceptive." And I could conclude the same. Population in itself is not a problem but the miseries of populations such as poverty and deprivation are problems which should be dealt. Children growing up in deprived conditions will weaken the foundations of a healthy nation. Poverty and deprivation can't be dealt head-on but through deep infrastructural origins involving the economy and labour market. There is a strong need to address structural issues to pull people out of chronic deprivation.

\section{Acknowledgements}

None.

\section{Conflict of interest}

Author declares that there is no conflict of interest.

\section{References}

1. Vigarello G. Concepts of Cleanliness: Changing Attitudes in France since the Middle Ages. Cambridge: Cambridge University Press; 1990.

2. Tomaselli S. Moral Philosophy and the Population Question. Population and Development Review. 1988;14(Suppl).

3. Gordon S. The History and Philosophy of Social Science. Routledge, New York, USA; 1991. 
4. Rao M. From Population Control to Reproductive Health: Malthusian Arithmetic. New Delhi: Sage Publications; 2004

5. Malthus TR. An Essay on the Principle of Population and a Summary View of the Principle of Population. Penguin, Harmonds worth, England; 1970.

6. Patnaik P. On the Political Economy of Underdevelopment. Economic and Political Weekly. 1973;8:4-6.

7. Meek RL. Marx and Engels on the Population Bomb. Berkeley: The Ramparts Press; 1977.

8. Greer G. Sex and Destiny: The Politics of Human Fertility. London: Secker and Warburg; 1984.

9. Kevles DJ. In the Name of Eugenics: Genetics and the Uses of Human Heredity. Cambridge, Massachusetts: Harvard University Press; 1995.

10. Bondestam L, Bergstrom S. Poverty and Population Control. London, England: Academic Press; 1980.

11. Hodgson D. The Ideological Origins of the Population Association of America. Population and Development Review. 1991;17(1):1-34.

12. Srinivas KR, Kanakamala K. Introducing Norplant: Politics of Coercion. Economic and Political Weekly. 1992;27(29).

13. Gordon L. Women's Body, Women's Right. Penguin, Harmondsworth, England; 1976.

14. Davis K. Population of India and Pakistan, Russel, New York, USA; 1968.

15. Bose A. From Population to People. New Delhi: BR Publishing; 1988.

16. Petchesky RP, Judd K. Negotiating Reproductive Rights: Women's Perspectives Across Countries and Cultures. Zed Books, London, England; 1998.

17. Haberland N, Diana M. Responding to Cairo: Case Studies of Changing Practice in Reproductive Health and Family Planning. Population Council, New York, USA; 2002.

18. Rao M, Sexton S. Introduction: Population, Health, and Gender in Neo-liberal Times. India: Sage Publications; 2010.

19. Sexton S, Nair S. A Decade and More after Cairo: Women's Health in a Free Market Economy. India: Sage Publications; 2010.

20. Report of the Expert Group on Population Policy. Government of India (Ministry of Health and Family Welfare), India; 1994.

21. Kumar RS. Neo-liberal Development and Reproductive Health in India: The Making of the Personal and the Political. Sage Publications; 2010;14(3).
22. The Pre-Conception and Pre-natal Diagnostic Techniques (Prohibition of Sex Selection) Act, 1994. Ministry of Health and Family Welfare (MoHFW), Government of India; 1994.

23. Leone T. How can demography inform health policy? Health Economics, Policy and Law. 2010;5:1-11.

24. Persson G. Demography and Public Health. Scandinavian Journal of Public Health. 2006;34(67):19-25.

25. Bloom D, Canning D, Sevilla J. The Demographic Divident: A New Perspective on Economic Consequences of Population Change. The Rand Corporation, Santa Monica CA; 2003.

26. Rao SK. Reducing Growth Rates of Population through Declines in Mortality: A Note. Economic and Political Weekly. 1974;9(38).

27. Rao SK. Population Growth and Economic Development: A Counter-Argument. Economic and Political Weekly. 1976;11(31-33):1149-1158.

28. Mamdani M. The Myth of Population Control: Family, Caste and Class in an Indian Village. London: Monthly Review Press; 1973;3(2):76-78.

29. Human Development Report 1992. United Nations Development Programme (UNDP). New York: Oxford University Press; 1992.

30. Hofsen E. Is There a Population Problem in the Industrialized Countries?. Poverty and Population Control. London: Academic Press; 1980.

31. Simon J, Wattenberg, Karl Z. Are World Population Trends a Problem? American Enterprises Institute, Washington DC, USA; 1984.

32. Davis K. The Amazing Decline of Mortality in Underdeveloped Areas American Economic Review. 1956;46(2).

33. The Medical Termination of Pregnancy Act (Act No. 34). Government of India (GOI), Government of India; 1971

34. The Medical Termination of Pregnancy Rules (Amendment). Government of India (GOI). 2003.

35. Hodgson D. Demography as Social Science and Policy Science. Population and Demographic Review. 1983;9(1):1-34.

36. Marx K. Capital Volume I. Penguin, Harmondsworth< England. 1976.

37. The Pre-natal Diagnostic Techniques (Regulation and Prevention of Misuse) Amendment Act. Ministry of Health and Family Welfare (MoHFW), 2002 (No. 14 of 2003), Government of India. 2003.

38. The Prohibition of Child Marriage Act, 2006. No. 6 of 2007 Gazette of India. Ministry of Law and Justice, Government of India; 2007. 